\title{
Ette Lipit Oksidasyonu ve Etkileyen Faktörler
}

\author{
Güleren Sabuncular ${ }^{1 *}$, Gamze Akbulut ${ }^{2}$, Mustafa Yaman ${ }^{3}$ \\ 1* Marmara Üniversitesi, Sağlık bilimleri Fakültesi, Beslenme ve Diyetetik Bölümü, İstanbul, Türkiye, (ORCID: 0000-0001-5922-295X), gulerenserin@hotmail.com \\ ${ }^{2}$ Gazi Üniversitesi, Sağlık bilimleri Fakültesi, Beslenme ve Diyetetik Bölümü, Ankara, Türkiye, (ORCID: 0000-0003-0197-1573), gakbulut@gazazi.edu.tr \\ 3 İstanbul Sabahattin Zaim Üniversitesi, Sağlık bilimleri Fakültesi, Beslenme ve Diyetetik Bölümü, İstanbul, Türkiye, (ORCID: 0000-0001-9692-0204), \\ mustafa.yaman@izu.edu.tr
}

(İlk Geliş Tarihi 26 Nisan 2021 ve Kabul Tarihi 10 Eylül 2021)

(DOI: $10.31590 /$ ejosat.924905)

\begin{abstract}
ATIF/REFERENCE: Sabuncular, G., Akbulut, G. \& Yaman, M. (2021). Ette Lipit Oksidasyonu ve Etkileyen Faktörler. Avrupa Bilim
\end{abstract} ve Teknoloji Dergisi, (27), 362-369.

\section{$\ddot{O} \mathbf{z}$}

Et, lipit ve hem demir açısından zengin bir besin olması nedeniyle lipit oksidasyonuna oldukça duyarlıdır. Et ürünlerinde bozulmanın mikrobiyal olmayan ana nedeni lipit oksidasyonudur. Hayvanın kesilmesinden başlayıp tüketime kadar oksidasyon süreci devam eder. Doymamış yağ asitleri serbest radikal zincir mekanizması yoluyla oksijen ile reaksiyona girerek hidrokarbonlar, aldehitler, ketonlar, alkoller, esterler gibi çok sayıda ikincil bileşik oluşturur. Malondialdehit ikincil lipit oksidasyonunda en çok oluşan aldehitlerdendir. Lipit oksidasyonu içsel ve dişsal birçok faktörden etkilenir. Etin bileşiminde bulunan metaller, prooksidan ve antioksidan enzimler içsel faktörleri oluştururken; depolama, paketleme, işleme teknikleri, pişirme, doğrama, kıyma gibi hazırlama teknikleri dışsal faktörleri oluşturmaktadır. Yağ asidi bileşimi, oksijen mevcudiyeti, pro- ve antioksidanların miktarları, katkı maddelerinin kullanımı (baharatlar, otlar ve tuz), işleme koşulları (1şınlama, pişirme, öğütme, kesme, karıştırma), paketleme (oksijen geçirgen, vakum, modifiye atmosfer ve aktif-paketleme) ve depolama (sıcaklık ve zaman) koşulları, ette lipit oksidasyonunun hızı ve gelişimi için önemlidir. Bu derlemede ette lipit oksidasyonunu etkileyen faktörler incelenmiştir.

Anahtar Kelimeler: Lipit, Oksidasyon, Et.

\section{Lipid Oxidation in Meat and Affecting Factors}

\begin{abstract}
Due to its rich lipid and heme iron content, meat is very sensitive to lipid oxidation. The main non-microbial cause of spoilage in meat products is lipid oxidation. The oxidation process continues from the slaughter of the animal to consumption. Unsaturated fatty acids react with oxygen through free radical chain mechanism and form numerous secondary compounds such as hydrocarbons, aldehydes, ketones, alcohols, esters. Malondialdehyde is one of the most common aldehydes in secondary lipid oxidation. Lipid oxidation is affected by many internal and external factors. While metals, prooxidant and antioxidant enzymes constitute internal factors in the composition of meat; Storage, packaging, processing techniques, cooking, and preparation techniques such as chopping and mincing meat are external factors. Fatty acid composition, the presence of oxygen, quantities of pro- and antioxidants, use of additives (spices, herbs and salt), processing conditions (irradiation, cooking, grinding, cutting, mixing), packaging (oxygen permeable, vacuum, modified atmosphere and active- packaging) and storage (temperature and time) conditions are important for the rate and development of lipid oxidation in meat. In this review, factors affecting lipid oxidation in meat were examined.
\end{abstract}

Keywords: Lipid, Oxidation, Meat.

\footnotetext{
*Sorumlu Yazar: gulerenserin@hotmail.com
} 


\section{Giriş}

Et, biyolojik değeri yüksek protein, demir, çinko, selenyum ve $\mathrm{B}_{12}$ vitamini içeriği ile dengeli beslenmenin önemli bir bileşenidir (Pereira ve Vicente, 2013). Etin yağ içeriği ve bileşimi besin değerinin önemli belirleyicisidir (Scollan ve ark., 2017). Lipitler, tüm et türlerinin önemli bileşenleridir ve etlerin birçok özelliğinden sorumludur. Etlerin lezzet ve aroma profili için önemlidir, yumuşaklığına ve sululuğa katkıda bulunur (Amaral ve ark., 2018). Et; protein, lipit ve hem demir açısından zengin bir besin olması nedeniyle üretim ve depolama sırasında meydana gelen kimyasal ve enzimatik işlemlerin sonucu olarak kolay bozulabilir özelliktedir. Ette bulunan lipitler ve proteinler oksidasyona duyarlıdır (Papuc ve ark., 2017). Lipit oksidasyonu, et ve et ürünlerinde kalitenin bozulmasının mikrobiyal olmayan ana nedenidir ve kesimden başlayıp son ürün tüketilene kadar aşamalı olarak devam eder. Lipit oksidasyonunda, temel olarak, doymamış yağ asitleri, serbest radikal zincir mekanizması yoluyla moleküler oksijen ile reaksiyona girer. Bu reaksiyondan türetilen hidroperoksitler, ilk oksidasyon ürünleri olarak kabul edilir ve diğer lipit türevi ürünlerin aksine, kokusuzdur ve aromaya herhangi katkısı yoktur (Dominguez ve ark., 2019). Bununla birlikte, bu bileşikler oldukça kararsızdır, bu nedenle hızla ayrışırlar ve hidrokarbonları, aldehitleri, ketonları, alkolleri, esterleri ve asitleri içeren çok sayıda ikincil bileşikle sonuçlanır (Ross ve Smith, 2006). Oksidasyon süreçlerinden türetilen tüm bileşikler içinde, aldehitler en önemli parçalanma ürünleri ve ette uçucu tada en büyük katkı sağlayanlar olarak kabul edilir. Lipit oksidasyonundan türetilen baskın aldehitler arasında n-alkanaller, trans-2-alkenaller, 4-hidroksi-trans-2-alkenaller ve malondialdehit (MDA) bulunur (Dominguez ve ark., 2019). Malondialdehit, ikincil lipit oksidasyonu sırasında oluşan en bol aldehitlerden biridir ve oksidasyon belirteci olarak en yaygın olarak kullanılanıdır (Barriuso ve ark., 2013).

Etin bileşimi, işleme teknikleri, pişirme veya 1sıtma koşulları, doğrama veya kıyma haline getirme, tuz, nitrit, baharat ve antioksidanlar gibi katkı maddelerinin kullanımı, paketleme ve depolama süresi gibi faktörler et ürünlerinin oksidatif stabilitesini etkiler (Mariutti ve Bragagnolo, 2017). Bu derlemede, ette lipit oksidasyonu ve çeşitli faktörlerin etkisi incelenmiştir.

\section{Lipit Oksidasyonu ve Mekanizması}

Lipit oksidasyonu, etlerdeki yağ dokularının bozulmasının başlıca nedeni olan, etin kalitesini doğrudan etkileyen kaçınılmaz bir süreçtir. Lipitler, oldukça karmaşık mekanizmalar yoluyla çeşitli faktörlerin neden olduğu oksidatif reaksiyonlara katılan, kimyasal olarak en kararsız besin bileşenlerinden biridir (Amaral ve ark., 2018). Üç ana yolla lipit oksidasyonu gerçekleşmektedir; foto-oksidasyon, enzimle katalize edilen oksidasyon ve otooksidasyon (Dominguez ve ark., 2019). Foto-oksidasyonun gelişimi için 1ş1k, 1şığa duyarlılaştırıcı ve oksijen gereklidir. Enzimle katalize edilen oksidasyon, lipoksijenaz ve siklooksijenaz ile ilgilidir ve uzun zincirli $n-3$ ve n-6 yağ asitlerinden gelen eikosanoidlerdeki biyolojik sistemlerde önemlidir. Serbest radikal oksidasyonu olarak da adlandırılan otooksidasyon etteki kötü koku oluşumuna, toksik bileşiklerin oluşumuna, fonksiyonel özelliklerin ve besin değerinin kaybına neden olur (Huang ve Ahn, 2019). Üç mekanizma arasında, sürekli bir serbest radikal zincir reaksiyonu olan oto-oksidasyon, ette lipit oksidasyonunun en önemli sürecidir. Enzimatik ve fotooksidasyon mekanizmaları, sadece başlangıç aşamasında hidroperoksitlerin oluşumunda oto-oksidasyondan farklılık gösterir (Dominguez ve ark., 2019).

Oto-oksidasyon, üç adımla karakterize edilen radikal bir zincir reaksiyonu olarak gerçekleşir; başlatma, yayılma ve sonlandırma (Králová, 2015). Genel olarak, başlatma fazında serbest radikaller oluşur, yayılma fazında reaktif bileşiklerin sayısı çoğalır ve sonlandırma fazında reaktif bileşikler bozunur veya reaktif olmayan bileşik vermek için reaksiyona girer (Dominguez ve ark., 2019).

Başlatma fazında doymamış bir yağ asidi ile bir oksijen molekülü etkileşime girer; ancak bu spontane bir reaksiyon değildir (Dominguez ve ark., 2018). Oto-oksidasyon, bir hidrojen atomunun çıkarılması için bir başlangıç aktivasyon enerjisi gerektirir, bu nedenle yüksek sıcaklıklar ve çift bağların varlığı ile tetiklenir. Foto-oksidasyon, 1şığa maruz kalma ve 1şı̆̆a duyarlılaştırıcıların mevcudiyeti altında üçlü moleküler oksijenin uyarılmasıyla oluşan yüksek derecede reaktif singlet oksijen türleri tarafindan tetiklenir (Barriuso ve ark., 2013). Başlatma fazında, hidrojen doymamış bir yağ asidinden çıkarıldığında elde edilen alkil radikali, konjuge dienler veya trienler oluşturmak için çift bağlı bir yeniden düzenleme ile stabilize edilme eğilimindedir. $\mathrm{Bu}$ alkil radikalleri, lipit oksidasyonunu başlatan ilk serbest radikallerdir. Başlangıç fazında, normalde, lipit oksidasyon ürünlerinin birikiminin yavaş olduğu bir gecikme fazı gözlenir (Dominguez ve ark., 2018). Bunun başlıca nedeni, hidroperoksit birikiminden önce serbest radikallerin yavaş oluşumu ve serbest radikallerin yağ asitleri ile etkileşimini önleyen antioksidanların varlığıdır (Barden ve Decker, 2016).

Oksidasyonun yayılma fazı, radikal oluşumunun büyütülmesiyle sonuçlanan lipit-lipit etkileşimleriyle gerçekleşir (Dominguez ve ark., 2018). Başlatma fazında elde edilen alkil radikali bir peroksil radikali oluşturmak için oksijen ile etkileşime girdiğinde yayılma fazı başlar. Bu peroksil radikali, hidrojenin başka bir doymamış yağ asidinden ayrılması için yeterli enerjiye sahiptir, böylece başka bir alkil radikali ve bir lipit hidroperoksit oluşturur. $\mathrm{Bu}$ nedenle yayılma, bir serbest radikalin bir yă asitinden diğerine aktarılmasını içerir (Barden ve Decker, 2016). Bununla birlikte, oksijenin yokluğunda yayılma meydana gelmez, bu da oksijenin varlığını lipit oksidasyon süreci için çok önemli kilar (Huang ve Ahn, 2019).

Lipit oksidasyonunun son adımı, lipit peroksil radikalinin birbiriyle reaksiyona girdiği ve / veya radikal olmayan ürünler oluşturmak için kendi kendini yok ettiği sonlandırma fazıdır (Min ve Ahn, 2005). Sonlandırma aşaması sırasında, iki radikal reaksiyona girerek yağ asidi dimerleri, trimerler ve oligomerler gibi radikal olmayan bir molekül oluşturur (Barden ve Decker, 2016). Benzer şekilde, bir antioksidan bileşik, bir hidrojen atomunu lipit oksidasyonundan türetilen radikal türlere aktarabilir. $\mathrm{Bu}$ reaksiyon, lipit radikalini nötralize eder ve antioksidan bileşikten çok daha az reaktif olan yeni bir radikal oluşturur (Dominguez ve ark., 2018).

\section{Lipit Oksidasyonunun Sağlığa Zararları}

Lipit oksidasyonu, raf ömrünü kısaltarak et ve et ürünlerinin kalitesinin bozulmasından sorumlu olan ana süreçtir ve renk, doku, besin değeri, tat ve aromayı etkilemektedir (Amaral ve ark., 2018). Etin duyusal nitelikleri üzerindeki zararlı etkileri yanında, hastalıklara neden olabilecek veya ürünleri tüketenlerin sağlığ üzerinde olumsuz etkilere sahip olabilecek serbest radikaller ve toksik bileşikler oluşur. 4-hidroksinonenal, malonaldehit gibi lipit 
oksidasyonunun birçok birincil ve ikincil yan ürünü, potansiyel karsinojenler olarak bilinir (Csala ve ark., 2015). Bu bağlamda, lipit hidroperoksitlerin hücre sitotoksisitesine katkıda bulunduğu ve düşük hidroperoksit konsantrasyonlarının hücreler üzerinde toksik etkiler oluşturacağı sonucuna varılmıştır (Angeli ve ark., 2011). Kolesterol oksidasyon ürünleri ayrıca arteriyel hücreler için kolesterolden daha tehlikelidir ve koroner hastalıklar, mutajenik aktivite ve ateroskleroz ile ilgilidir. Lipit oksidasyonundan türetilen aldehitlerin ve oksisterollerin proinflamatuvar, sitotoksik ve mutajenik etkilere sahip olduğu, bu nedenle, oksidasyon ürünlerinin sayısız hastalığın gelişiminde veya ilerlemesinde rol oynadığı açıktır (Dominguez ve ark., 2019). Karbonil bileşikleri hücresel sinyal transdüksiyonunu etkileyebilir, hidroperoksitlerin DNA'ya zarar verdiği bilinmektedir ve epoksitler ve hidrojen peroksit yan ürünleri bilinen kanserojenlerdir. Oksidatif süreçler sırasında üretilen lipit radikalleri, reaktif oksijen türleri, reaktif nitrojen türleri ve reaktif sülfür türleri dahil olmak üzere serbest radikaller, insan vücudundaki oksidatif stresi artırabilir (Huang ve Ahn, 2019). Mevcut literatür, diyet oksidasyon bileşiklerinin bir kısmının lenfte veya doğrudan kan dolaşımına emildiğini ve biyolojik sistemlerde oksidatif hasarı indükleyebildiğini göstermektedir (Kanner, 2007; Van Hecke ve ark. ,2016). Oksidatif stres birçok hastalığın etiyolojisi ve ilerlemesindeki önemli faktörlerden biridir (Macho-González ve ark., 2020). Doğrudan veya dolaylı olarak inflamatuvar hastalıklar, kanser, diyabet, Alzeheimer hastalığı, Pakinson hastalığı, ateroskleroz, kalp yetmezliği, karaciğer yağlanması, kronik yorgunluk sendromu, obezite ve depresyon gibi çeşitli hastalıklarda rol oynamaktadır (Huang ve Ahn, 2019).

\section{Lipit Oksidasyonunu Etkileyen Faktörler}

Lipit oksidasyonu, substratlar ve katalizörler arasındaki çok karmaşık reaksiyonlar ve etkileşimlerle çoklu mekanizmaları içeren bir süreçtir. Bu reaksiyonlar farklı faktörlerden etkilenir. Aslında, hem içsel (yağ asidi bileşimi, hem-proteinler, metaller, prooksidan enzimler, antioksidan enzimler, vitaminler vb.) hem de dışsal faktörler (işleme ve saklama koşulları vb.) oksidatif reaksiyonları teşvik edebilir veya inhibe edebilir. Bu nedenle etin oksidatif stabilitesi, anti- ve prooksidan bileşiklerin dengesine bağlıdır (Dominguez ve ark., 2019). Yağ asidi bileşimi, oksijen mevcudiyeti, serbest radikal başlatıcıların/propagatörlerin varlığg, pro- ve antioksidanların miktarları, katkı maddelerinin kullanımı (baharatlar, otlar ve tuz gibi), işleme koşulları (1şınlama, pişirme, öğütme, kesme, karıştırma) ve paketleme (oksijen geçirgen, vakum, modifiye atmosfer ve aktif-paketleme, vb.) ve depolama (sıcaklık ve zaman) koşulları, ette lipit oksidasyonunun hızı ve gelişimi için önemlidir (Huang ve Ahn, 2019).

\subsection{Lipit Miktarı ve Kompozisyonu}

Hayvanın türü veya ırkı, yetiştirme sistemi, kas tipi, anatomik konum veya hayvanların yemi gibi faktörler et bileşimini önemli ölçüde değiştirdiğinden, dolaylı olarak oksidasyonu etkiler. Lipitler, oksidasyonunun gelişimi için ana substrat olduklarından en önemli parametrelerden biridir (Dominguez ve ark., 2019). Etteki lipitler kas içi, kaslar arası ve deri altı yağ depolarında esas olarak gliserol esterler, kolesterol, fosfolipitler ve yağ asit esterleri şeklinde depolanır (Scollan ve ark., 2017). Büyükbaş hayvan etinin lipit içeriği \%2,5 ila \%24 arasında değişir; kaslar arası lipitler esas olarak triasilgliserollerden oluşur ve kas içi lipitler ağırlığın yaklaşık \%5'ini oluşturur ve fosfolipitlerden ve triasilgliserollerden oluşur (Guyon ve ark., 2016). Kas içi lipit artışı, yağ hücrelerinin (trigliseridler) hacminde bir artışa neden olurken, membranların sayısı değişmediğinden fosfolipitlerin sayısı sabit kalmaktadır (Dominguez ve ark., 2019). Lipitlerin çoğunluğu trigliserid fraksiyonunda olmasına rağmen, fosfolipitlerin lipit oksidasyonunun gelişiminde temel olduğu ileri sürülmüştür. $\mathrm{Bu}$ yüksek fosfolipit reaktivitesinin iki ana açıklaması vardır. Birincisi, membranlardaki lipitler oksidasyon katalitik bölgelerine daha yakın olduğundan, lipit oksidasyonunun yayılma fazını kolaylaştırır. İkinci olarak, fosfolipitlerin trigliseridlerden daha yüksek miktarda çoklu doymamış yağ asitlerine sahiptir (Amaral ve ark., 2018).

Bazı yazarlar, lipit miktarının oksidasyona katkıda bulunduğunu onaylarken (Van Hecke ve ark., 2014; Van Hecke ve ark., 2016b; Steppeler ve ark., 2016), diğer yazarlar yă̆ asitleri bileşiminin yağ miktarından daha önemli olduğuna işaret etmektedir (Min ve ark., 2008). Tablo 1'de lipit miktarı ve kompozisyonunun lipit oksidasyonuna etkisi gösterilmiştir. Steppeler ve ark., (2016) yă̆ miktarı yüksek ette toplam etin gramı başına MDA konsantrasyonunun yüksek olması ile birlikte yağ gramı başına MDA konsantrasyonlarının düşük yağlı ette daha yüksek olduğunu bulmuşlardır. Bunun yağsız ette biraz daha yüksek sayıda çift bağ ve daha yüksek toplam demir içeriği ile açıklanıp açıklanamayacağının belirsizliğine işaret etmişlerdir. Yağsız ette (çok düşük kas içi yağ içeren), yüksek oranda fosfolipit olması yağsız eti oksidasyona çok duyarlı hale getirir. $\mathrm{Bu}$ nedenle oksidatif duyarlılık açısından yağın doymamışlı̆̆ı yağ miktarından çok daha önemli bir parametredir (Dominguez ve ark., 2019). Doymamış grupların (çift bağ) artması ile lipit oksidasyonu önemli ölçüde artar (Amaral ve ark., 2018). Çoklu doymamış yağ asitine bir çift bağ eklenmesinin, yağ asidinin oksitlenme oranını en azından iki katına çıkardığı, cis biçiminin genellikle trans biçiminden daha kolay oksitlendiği gösterilmiştir. $\mathrm{Bu}$ nedenle, doymamışlığın artmasıyla lipit oksidasyonu artar (Barden ve Decker, 2016). Çoklu doymamış yağ asitleri, tekli doymamış yağ asitlerinden daha hızlı oksitlenir. Linoleik asit (C18: 2) oksidasyonu, oleik asidin (C18: 1) oksidasyonundan on kat daha hızlı gerçekleşirken, oleik asitin oksidasyonu linolenik asitin oksidasyonundan (C18: 3) 20 ila 30 kat daha yavaş gerçekleşir (Amaral ve ark., 2018). Kırmızı etlere göre çok daha yüksek doymamışlık derecesine sahip olduğundan kanatlı etinde bu özellik çok önemlidir (Dominguez ve ark., 2019).

\subsection{Metal İyonları}

Enzimler, 1şık, yüksek sıcaklıklar gibi metaller ve metaloproteinler de öncelikle serbest radikaller ve/veya reaktif oksijen türleri üreten reaksiyonlar yoluyla oksidasyonu hızlandırdıklarından, başlangıç aşamasında lipit oksidasyonunu stimüle edebilir (Barden ve Decker, 2016). Geçiş metalleri arasında demir, ana katalizördür ve reaktif oksijen türlerinin üretimindeki rolünden dolayı lipit oksidasyonunda kritik bir rol oynar (Huang ve Ahn, 2019). Metal iyonu bir elektronu hidroperoksite aktarır ve bu da parçalanmasına neden olur. $\mathrm{Bu}$ nedenle, ette bulunan demir hidroperoksitlerin ayrışması için önemli bir katalizördür ve demir iyonu ile reaksiyonda ferrik iyondan daha hızlıdır (Dominguez ve ark., 2019). Hem pigmentleri de güçlü prooksidanlar olarak kabul edilir. (Huang ve Ahn, 2019). Demir, Fenton reaksiyonu yoluyla hidroksil radikali üretimini katalize edebilir. Etteki lipit oksidasyonundan birincil olarak serbest demir ve/veya ferril miyoglobinin sorumlu olduğu öne sürülmüştür. Yüksek miyoglobin konsantrasyonuna sahip kasların lipit oksidasyonuna daha duyarlı olduğu bilinmektedir. Metmiyoglobinin hidrojen peroksit veya lipit hidroperoksitler ile 
etkileşiminin, serbest radikal zincir reaksiyonunu başlatabilen ferrilmiyoglobin oluşumuyla sonuçlandığına dair kanıtlar vardır (Amaral ve ark., 2018). Daha yüksek demir ve miyoglobin konsantrasyonları, daha yüksek oranda lipit oksidasyonu ile ilişkilidir (Faustman ve ark., 2010). Min ve ark. (2010), serbest iyonik demir ilave edilen pişmiş tavuk etinde lipit oksidasyonunun miyoglobine göre daha belirgin olduğunu bulmuş ve serbest iyonik demirin lipit oksidasyonu için ana katalizör olduğunu öne sürmüştür. Etler arasında sığır eti, lipit oksidasyonuna en duyarlı olanıdır. Hem pigment içeriği ve katalaz aktivitesindeki farklılıkların çiğ ette lipit oksidasyon oranını belirlediği öne sürülmüştür. Daha yüksek hem pigment içeriğine (sığır eti) sahip etlerin, oksimiyoglobin oto-oksidasyonu sırasında daha az hem pigmentli etlere göre daha fazla hidrojen peroksit $\left(\mathrm{H}_{2} \mathrm{O}_{2}\right)$ ürettikleri belirtilmiştir (Min ve ark., 2008). Metal iyonların lipit oksidasyonuna etkisi Tablo 1'de özetlenmiştir.

\subsection{Depolama, İşleme, Hazırlama ve Pişirme}

Sıcaklık, 1şık ve oksijenin varlığı gibi faktörler oksidatif süreçleri artırır. Depolama koşullarının lipit oksidasyonunun artmasında çok büyük önemi vardır. Benzer şekilde, belirli işleme teknikleri de oksidasyonu stimüle eder (Dominguez ve ark., 2019). Kesme, doğrama işlemleri, kemik çıkarma, ısıtma, olgunlaştırma, katkı maddeleri, oksijene maruz kalma gibi çeşitli faktörler et ve et ürünlerindeki lipit oksidasyon oranını etkileyebilir (Amaral ve ark., 2018). Genel olarak, tüm işlemler oksidatif reaksiyonları teşvik eden kas zarının bozulmasına neden olur. $\mathrm{Bu}$ durum, serbest kalan membran fosfolipitlerinin işlenmesi, oksidasyonu teşvik eden oksijen, enzimler veya metaller gibi prooksidan bileşenlerle teması arttırmakla ilgilidir (Dominguez ve ark., 2019).

\section{Depolama/Saklama}

Oksijen, depolama sırasında lipit oksidasyonuna katkıda bulunan önemli bir faktördür. Oksijen yokluğunda, prooksidanların depolama sırasında oksidasyon üzerinde minimum etki gösterdiği gösterilmiştir (Amaral ve ark., 2018). Dondurma, et ve et ürünleri için önemli saklama yöntemlerinden biridir. Dondurarak depolama sırasında, farklı et bileşenleri arasında birçok reaksiyon meydana gelebilir. Örneğin, dondurulmuş ette fosfolipitlerin lipazlar tarafindan parçalanması gözlemlenmiştir. $\mathrm{Bu}$ reaksiyonlar çeşitli donma sıcaklıklarında ve depolama sürelerinde meydana gelir (Soyer ve ark., 2010). Bazı yazarlar depolama sıcaklığının düşmesi ile lipit oksidasyon oranının azaldığını söylerken (Wang ve ark., 2020), diğer yazarlar farklı sıcaklıkların etkisinin olmadığını, ancak saklama süresinin, etlerin peroksit değeri üzerine önemli bir etkiye sahip olduğunu belirtmiştir (Coombs ve ark., 2018; Soyer ve ark., 2010; Muela ve ark. 2015). Soyer ve arkadaşlarının (2010) yaptığı çalışmaya göre 6 ay boyunca farklı sicaklıklarda depolanmanın tavuk etindeki lipit oksidasyonuna etkisi olmadığı bulunmuştur. Bununla birlikte, tavuk but ve gögüs etinde ortalama peroksit değeri, 2 ve 3 aylık depolama sonunda yükselmiş ve 6 aylık depolamadan sonra düşmüştür. Artışın muhtemel sebebini, depolamanın 1, 2 ve 3. ayları sırasında peroksit oluşumunun daha hızlı olması, daha sonra ise peroksitlerin bozunması ile açıklamışlardır.

Depolama sürecinde besinlerin kalitesini koruyan ve oksijene maruz kalmayı engelleyen faktörlerden biri de ambalajlamadır (Aday, 2021). Depolama sırasında oksijenin ete erişimi, sıcaklık ve süreden başka, kullanılan paketleme yöntemlerinden ve malzemelerden de etkilenebilir (Huang ve Ahn, 2019). Yüksek miktarda oksijen ile ambalajlanan ette lipit oksidasyonu nispeten kısa bir süre içinde gerçekleşir. Öte yandan, paketlerdeki oksijen eksikliği, oksidasyon oluşumunu en aza indirebilir (Orkuzs ve ark., 2017). Vakumlu paketleme, modifiye atmosfer paketleme ve oksijen geçirgen paketleme, çiğ ve pişmiş et için kullanılan yaygın yöntemlerdir, ancak pişirilmiş et saklama sırasında oksidatif değişikliklere daha duyarlı olduğundan, vakumlu paketleme, pişmiş et için tercih edilen yöntemdir. Bununla birlikte, vakumlu paketleme bile oksijeni tamamen engelleyemez, çünkü paketleme malzemeleri de oksijen geçirgendir ve paketlenmiş ette bir miktar artık oksijen kalır (Huang ve Ahn, 2019). Oksijen geçirgen paketleme sıklıkla çiğ etler için yaygın olsa da, vakumlu ve modifiye atmosfer paketleme daha uzun raf ömrü sağlar (McMillin, 2017). Tablo 1'de farklı et türlerine uygulanan depolama ve paketleme yöntemlerinin lipit oksidasyonuna etkisi verilmiştir.

\section{İşleme teknikleri}

Sodyum klorür et endüstrisindeki en önemli katkı maddelerinden biridir (Amaral ve ark., 2018). Tuz, gidaların su aktivitesini azaltma kabiliyetinin doğrudan bir sonucu olarak koruyucu ve antimikrobiyal özelliklere sahiptir. Et ürünlerine tuz eklenmesi, su tutma kapasitesini iyileştirir ve ayrıca bazı enzim faaliyetlerini etkileyerek etin lezzetini artırır. Bununla birlikte, tuzun lipit oksidasyonunu hızlandırdığ 1 ve et ve et ürünlerinin raf ömürlerini azaltan istenmeyen renk ve tat değişikliklerine neden olduğu da bildirilmektedir (Mariutti ve Bragagnolo, 2017). Bazı çalışmalar, tuzun çeşitli et türlerinde pro-oksidan olduğunu işaret ederken (Gheisari ve Motamedi, 2010; Gheisari ve ark., 2010; Jin ve ark., 2012), bazı çalışmalar tuzun etkisi olmadığını (Kong ve ark., 2008; Vara-Ubol ve Bowers, 2001; Sakai ve ark., 2006) ve hatta antioksidan etkileri olduğunu (Sakai ve ark., 2006) belirtmişlerdir. Tablo 1'de farklı et türlerine çeşitli konsantrasyonlarda eklenen tuzun lipit oksidasyonuna etkisi verilmiştir.

Sodyum klorürün pro-oksidan etkisinin olası mekanizmaları, oksitleyici ajanların lipit substratlara erişimini kolaylaştıran hücre zarı bütünlüğünü bozma kapasitesine; demir iyonlarını hem proteinler gibi demir içeren moleküllerden serbest bırakmasına veya katalaz, glutatyon peroksidaz ve süperoksit dismutaz gibi antioksidan enzimlerin aktivitesini inhibe etmesine atfedilir (Amaral ve ark., 2018; Mariutti ve Bragagnolo, 2017). Endojen antioksidan enzimler, özellikle katalaz ve glutatyon peroksidaz, depolanan ette oksidasyonun başlamasını potansiyel olarak geciktirebilir. Gheisari, ve Motamedi'nin (2010) yaptığ 1 çalışmada, lipit oksidasyonu ve glutatyon peroksidaz aktivitesi arasındaki negatif ilişki ile tuzlanmış ette hızlandırılmış lipit oksidasyonunun kısmen glutatyon peroksidaz aktivitesinde bir düşüşle ilişkili olabileceğini göstermiştir.

\section{Hazırlama ve pişirme}

Oksijen maruziyetinin, lipit oksidasyonu gelişimi için önemli faktörlerden biri olması nedeniyle, kesme, öğütme, kemik sıyırma ve pişirme gibi işlemler oksidatif bozulmanın gelişimini hızlandırabilir. $\mathrm{Bu}$ işlemlerde, membranların yırtılması sonucu fosfolipitlerin oksijene maruz kalması ve boyut küçültme ile temas yüzeyinin artması, lipit oksidasyonuna yol açan mekanizmalar olarak açıklanmıştır (Amaral ve ark., 2018). Kesme, öğütme ve doğrama etin yüzey alanını arttırır. Pişirme birçok antioksidan enzimi etkisiz hale getirir. Ayrıca, tüm bu işlemler et lipitlerini oksijene ve katalizörlere maruz bırakır ve oksidatif değişiklikleri hızlandırır (Huang ve Ahn, 2019). Bununla birlikte pişirme sırasında oksijen bulunabilirliği kısıtlandığında pişmiş ette daha düşük MDA seviyeleri 
gözlemlenebilmektedir. Sous-vide pişirme sırasında azalan oksijen mevcudiyeti, ikincil lipit oksidasyonunu sınırlayabilir (Ortuño ve ark., 2020).

Ette oksidasyon reaksiyonlarının gelişimi pişirme yöntemine, sıcaklığına ve süresine bağlıdır. Pişirme sırasında yüksek sıcaklık ette oksidasyon süreçlerinin artmasına neden olur (Broncano ve ark., 2009). Pişirme, fosfolipitleri oksijene maruz bırakmanın yanı sıra, hem-olmayan demirin hem pigmentlerden salınmasını da destekler. Yavaş 1sıtmanın, hızlı 1sıtmaya göre hem olmayan demirin salınımını daha hızlı arttırdığı gösterilmiştir (Amaral ve ark., 2018). Farklı pişirme yöntemleri ile lipit oksidasyonu gelişiminin incelendiği bir çalışmada firında pişirme yönteminde uzun süre (20 dakika) 1s1 uygulanması, 1zgara yönteminde daha kısa sürede (4 dakika) daha yüksek sıcaklık $\left(190^{\circ} \mathrm{C}\right)$ uygulamanın neden olduğu değişikliklere göre daha yüksek oksidasyon ürettiği bulunmuştur. Oksidasyonun, düşük sicaklıkta uzun süre pişirmeden daha fazla etkilendiğini belirtilmiştir (Broncano ve ark., 2009). Tablo 1 'de farklı et türlerine uygulanan pişirme yöntemlerinin lipit oksidasyonuna etkisi verilmiştir.

\section{Sonuç}

Besin ögesi içeriği ile dengeli beslenmenin önemli bir bileşeni olan et, yă̆ içeriği ve bileşimi nedeniyle lipit oksidasyonuna oldukça duyarlıdır. Lipit oksidasyonu, et ve et ürünlerinin duyusal kalitesinin bozulması yanında sağlığa zararlı etkileri nedeniyle dikkate alınması gereken bir süreçtir. Lipit oksidasyon ürünleri çeşitli hastalıklarla ilişkili olan oksidatif stresi arttırmaktadır. Bu nedenle oksidatif stresi önlemek için lipit oksidasyonunun önlenmesi önemlidir. Lipit oksidasyonu ette depolama, paketleme, işleme, hazırlama ve pişirme aşamalarında uygulanan yöntem, süre ve sicaklığa bağlı olarak oluşabilmektedir. Ette lipit oksidasyon mekanizmaları, oksidasyonun kontrolü için yeni yaklaşımlar geliştirmek ve mevcut yöntemleri iyileştirmek için daha fazla çalışmaya ihtiyaç vardir.

Tablo 1. Lipit Oksidasyonunu Etkileyen Faktörler

\begin{tabular}{|c|c|c|c|}
\hline & Yöntem & Sonuç & Referans \\
\hline \multicolumn{4}{|l|}{ Lipit miktarı } \\
\hline $\begin{array}{l}\text { Yağlı }(\% 15) \\
\text { ve yağsız }(\% 1) \\
\text { pişmiş sığır eti }\end{array}$ & In vitro sindirim & $\begin{array}{l}\text { Yüksek yağlı sığır etinin sindirimi, az yağlı sığır etine kıyasla } 11 \text { kat } \\
\text { daha yüksek MDA, } 14 \text { kat daha yüksek 4-HNE ve } 8 \text { kat daha yüksek } \\
\text { HEX konsantrasyonları ile sonuçlanmıştır. }\end{array}$ & $\begin{array}{l}\text { Van } \\
\text { Hecke ve } \\
\text { ark., } \\
2016 b\end{array}$ \\
\hline $\begin{array}{l}\% 1, \% 5 \text { ve } \\
\% 20 \text { yağli } \\
\text { domuz eti }\end{array}$ & In vitro sindirim & $\begin{array}{l}\text { Yağ içeriği arttıkça MDA, 4-HNE ve HEX konsantrasyonları } \\
\text { artmıştır. }\end{array}$ & $\begin{array}{l}\text { Van } \\
\text { Hecke ve } \\
\text { ark., } 2014\end{array}$ \\
\hline $\begin{array}{l}\% 2,3 ; \% 10 \text { ve } \\
\% 14 \text { yağlı } \\
\text { pişmiş sığır eti }\end{array}$ & In vitro sindirim & $\begin{array}{l}\text { Yağ içeriği ile aldehit oluşumu arasında pozitif bir ilişki olduğu ve } \\
\text { düşük yağlı (\% 2,3) sığır filetosunda yağlı ( } \% \text { 10-14) olanlara göre } \\
\text { önemli ölçüde daha düşük MDA eşdeğerleri olduğu gösterilmiştir. }\end{array}$ & $\begin{array}{l}\text { Steppeler } \\
\text { ve ark., } \\
2016\end{array}$ \\
\hline \multicolumn{4}{|c|}{ Yağ asiti bileşimi, doymamışlık derecesi } \\
\hline $\begin{array}{l}\text { Çiğ ve pişmiş } \\
\text { siğır filetosu, } \\
\text { domuz } \\
\text { filetosu, tavuk } \\
\text { göğüs eti ve } \\
\text { tavuk but }\end{array}$ & $\begin{array}{l}3 \text { ve } 7 \text { gün soğukta } \\
\text { depolama }\end{array}$ & $\begin{array}{c}\text { Pişmiş sığır filetosu ve tavuk but etinin TBARS değerleri, } 7 \text { günlük } \\
\text { depolamadan sonra domuz filetosu ve tavuk göğüs etinden yaklaşık } 2 \\
\text { kat daha fazla bulunmuştur. Çiğ tavuk but etindeki ( } 2,44 \mathrm{~g} / 100 \mathrm{~g} \text { et) } \\
\text { toplam PUFA miktarı, sığır filetosu, domuz filetosu ve tavuk göğüs } \\
\text { etinden (sırasıyla } 0,74,0,72 \text { ve } 0,69 \mathrm{~g} / 100 \mathrm{~g} \text { et) daha yüksek } \\
\text { bulunmuştur. }\end{array}$ & $\begin{array}{l}\text { Min ve } \\
\text { ark., } 2008\end{array}$ \\
\hline $\begin{array}{l}\text { Tavuk but ve } \\
\text { göğüs eti }\end{array}$ & $\begin{array}{l}-7,-12 \text { ve }-18^{\circ} \mathrm{C} ; 6 \text { ay } \\
\text { soğuk depolama }\end{array}$ & $\begin{array}{l}\text { Göğüs etinin peroksit değeri, but etinden daha yüksek bulunmuştur. } \\
\text { But etinin lipit içeriği göğüs etinden daha yüksek olmasına rağmen, } \\
\text { göğ̈̈s eti, but etine göre iki kat fazla fosfolipit içeriyordu. Göğüs } \\
\text { etinde daha yüksek peroksit değeri, daha yüksek fosfolipit içeriğine } \\
\text { bağlanmıştır. }\end{array}$ & $\begin{array}{l}\text { Soyer ve } \\
\text { ark., } 2010\end{array}$ \\
\hline \multicolumn{4}{|c|}{ Hem demir içeriği } \\
\hline $\begin{array}{l}\text { Siğır filetosu, } \\
\text { domuz } \\
\text { filetosu, tavuk } \\
\text { göğüs eti ve } \\
\text { tavuk but }\end{array}$ & $\begin{array}{l}3 \text { ve } 7 \text { gün soğuk } \\
\text { depolama }\end{array}$ & $\begin{array}{l}\text { 3. ve 7. günlerde, sığır filetosunun TBARS değerleri, domuz filetosu, } \\
\text { tavuk göğüs ve tavuk but etlerinden önemli ölçüde daha yüksek } \\
\text { bulunmuş ve depolama sırasında çiğ etler arasında TBARS artışı, sığır } \\
\text { filetosunda en yüksektir. Çiğ domuz filetosu, tavuk göğüs ve tavuk } \\
\text { but etinin TBARS değerleri, önemli ölçüde artmamıştır. }\end{array}$ & $\begin{array}{l}\text { Min ve } \\
\text { ark., } 2008\end{array}$ \\
\hline $\begin{array}{l}\text { Siğır etinin } \\
\text { Longissimus }\end{array}$ & 9 günlük depolama & $\begin{array}{c}\text { Longissimus Dorsi kasta, hem demir konsantrasyonu lipit } \\
\text { oksidasyonu ile orta derecede bir korelasyon göstermiştir. Aynı kastaki } \\
\text { non hem demir, lipit oksidasyonu ile zayıf bir şekilde korelasyon }\end{array}$ & $\begin{array}{l}\text { Purohit ve } \\
\text { ark., } 2015\end{array}$ \\
\hline
\end{tabular}




\begin{tabular}{|c|c|c|c|}
\hline $\begin{array}{l}\text { dorsi ve Psoas } \\
\text { major kasları }\end{array}$ & & $\begin{array}{l}\text { göstermiştir. Psoas Major'de hem demiri, lipit oksidasyonu ile güçlü } \\
\text { bir şekilde ilişkili bulunmuştur. Aynı kasta non hem demir, lipit } \\
\text { oksidasyonu ile zayıf bir korelasyon göstermiştir. }\end{array}$ & \\
\hline $\begin{array}{l}\text { Çiğ tavuk ve } \\
\text { slğır eti, } 3 \\
\text { hafta soğuk } \\
\text { depolama }\end{array}$ & $\begin{array}{l}\text { Metmyoglobin (MetMb) } \\
\text { (doğal kas içeriğindekinin } \\
\text { iki katı) ilavesi }\end{array}$ & $\begin{array}{l}\text { Hem pigmenti ve lipit oksidasyon indeksleri, sığır etinde tavuktan } \\
\text { daha yüksek bulunmuştur. MetMb ilavesinin tavuk eti ve sığır etinde } \\
\text { lipit oksidasyonu üzerinde artırıcı bir etkisi olmamıştır. }\end{array}$ & $\begin{array}{l}\text { Gheisari } \\
\text { ve ark., } \\
2010\end{array}$ \\
\hline \multicolumn{4}{|c|}{ Depolama koşulları } \\
\hline \multicolumn{4}{|c|}{ Süre ve slcaklık } \\
\hline $\begin{array}{l}\text { Tavuk göğüs } \\
\text { ve but eti }\end{array}$ & $\begin{array}{l}-7,-12 \text { ve }-18^{\circ} \mathrm{C} ; 6 \text { ay } \\
\text { soğuk depolama }\end{array}$ & $\begin{array}{l}\text { MDA konsantrasyonu 2. aya kadar hızlı, daha sonra yavaş artmıştır. } 6 \text {. } \\
\text { ayda başlangıca göre but etinde } 3 \text { kat, göğ̈̈s etinde } 2,5 \text { kat artmıştır. } \\
\text { Farklı sıcaklıkların MDA konsantarasyonu üzerine etkisi olmamıştır. }\end{array}$ & $\begin{array}{l}\text { Soyer ve } \\
\text { ark., } 2010\end{array}$ \\
\hline Kuzu eti & $\begin{array}{l}-12 \text { ve }-18 \mathrm{C} ; 8 \text { hafta } \\
\text { dondurma }\end{array}$ & $\begin{array}{c}\text { Depolama süresi arttıkça TBARS düzeylerinin arttığı gözlenmiştir. } \\
\text { Sıcaklığın etkisi anlamlı bulunmamıştır. }\end{array}$ & $\begin{array}{l}\text { Coombs } \\
\text { ve ark., } \\
2018\end{array}$ \\
\hline Kuzu eti & $\begin{array}{l}21 \text { ay dondurulmuş } \\
\text { saklama }\end{array}$ & Depolama süresi arttıkça lipit oksidasyonunun arttı̆̆ gözlenmiş̧ir. & $\begin{array}{l}\text { Muela ve } \\
\text { ark., } 2015\end{array}$ \\
\hline Tavşan eti & $\begin{array}{l}+4,-4,-12,-18^{\circ} \mathrm{C} \text { soğuk } \\
\text { depolama }\end{array}$ & $\begin{array}{l}\text { Değerlendirme dönemlerinde tüm numuneler için TBARS değerleri } \\
\text { saklama süresi ile artmış ve } 4{ }^{\circ} \mathrm{C} \text { 'de saklanan numuneler diğer grup } \\
\text { numunelere göre daha yüksek oranda artış göstermiştir. }\end{array}$ & $\begin{array}{l}\text { Wang ve } \\
\text { ark., } 2020\end{array}$ \\
\hline \multicolumn{4}{|c|}{ Paketleme ve oksijen } \\
\hline Kaz eti & $\begin{array}{l}\text { Modifiye atmosfer ve } \\
\text { vakum paketleme ile } 11 \\
\text { gün }\end{array}$ & $\begin{array}{l}\text { Hem modifiye atmosferde hem de vakumda paketlenen numuneler } \\
\text { için depolamanın } 11 \text { günü içinde TBARS değerlerinde artış olmuştur. } \\
\text { Paketlenmemiş örneklerle karşılaştırıldığında TBARS değerleri } \\
\text { modifiye atmosfer için } \% 260,47 \text { ve vakum için } \% 18,60 \text { artmıştır. }\end{array}$ & $\begin{array}{l}\text { Orkuzs ve } \\
\text { ark., } 2017\end{array}$ \\
\hline Dana kıyma & $\begin{array}{l}\text { (1)Yüksek oksijenli } \\
\text { modifiye atmosfer, } \\
\text { (2)karbon monoksit } \\
\text { modifiye atmosfer, } \\
\text { (3)vakum paketleme ve } \\
\text { (4)aerobik paketleme ile } 3 \\
\text { gün depolama }\end{array}$ & $\begin{array}{c}\text { Paketleme, köftelerde lipit oksidasyonunu etkilemiştir. } \\
\text { Vakum paketlemede 1. günde diğer yöntemlere göre daha düşük } \\
\text { TBARS gözlenmiştir. } \\
\text { Üçüncü günde yüksek oksijenli modifiye atmosfer paketleme ve } \\
\text { aerobik paketlemede TBARS artarken, karbon monoksit modifiye } \\
\text { atmosfer, vakum paketlemede depolama sırasında değişiklik } \\
\text { gözlenmemiştir. }\end{array}$ & $\begin{array}{l}\text { Suman ve } \\
\text { ark., } 2010\end{array}$ \\
\hline \multicolumn{4}{|c|}{ İşleme teknikleri } \\
\hline $\begin{array}{l}\text { Sığır, deve ve } \\
\text { tavuk göğüs } \\
\text { eti }\end{array}$ & $\begin{array}{l}\mathrm{NaCl} \text { ve } \mathrm{KCl} \text { ilavesi ile } 4 \\
{ }^{\circ} \mathrm{C} \text { 'de } 4 \text { günlük depolama }\end{array}$ & $\begin{array}{l}\text { Depolama sırasında TBARS ve peroksit değerleri artmış ve glutatyon } \\
\text { peroksidaz aktivitesi azalmıştır, ancak katalaz aktivitesi stabildir. Tuz } \\
\text { tipinin enzim aktiviteleri üzerinde tutarlı bir etkisi bulunmamıştır. }\end{array}$ & $\begin{array}{l}\text { Gheisari, } \\
\text { ve } \\
\text { Motamedi } \\
, 2010\end{array}$ \\
\hline $\begin{array}{l}\text { Siğır ve tavuk } \\
\text { eti }\end{array}$ & $\begin{array}{l}\% 0, \% 1 \text { ve } \% 6 \mathrm{Na} \mathrm{Cl} \\
\text { ilavesi ile } 3 \text { hafta soğuk } \\
\text { depolama }\end{array}$ & $\begin{array}{l}\text { Peroksit değeri ve TBARS, hem tavuk eti hem de slğır etinde } \\
\text { depolamada önemli ölçüde artmıştır. \%6 tuz ilaveli grup, her iki türde } \\
\text { de en yüksek TBARS ve peroksit değerine sahip bulunmuştur. }\end{array}$ & $\begin{array}{l}\text { Gheisari } \\
\text { ve ark., } \\
2010\end{array}$ \\
\hline Domuz eti & $\begin{array}{l}\% 0,5, \% 1,0, \% 2,0, \% 3,0 \\
\text { veya } \% 4,0 \mathrm{NaCl} ; 7 \text { gün } \\
\text { depolama }\end{array}$ & $\begin{array}{l}\mathrm{NaCl} \text {, önemli pro-oksidan etki göstermiştir. Tuz eklenmeyen kontrol } \\
\text { örneğine göre tüm konsantarasyonlarda daha yüksek TBARS düzeyi } \\
\text { gözlenmiş ve konsantrasyon arttıkça TBARS düzeyi yükselmiştir. }\end{array}$ & $\begin{array}{l}\text { Jin ve } \\
\text { ark., } 2012\end{array}$ \\
\hline Levrek fileto & $\begin{array}{l}\text { tuzsuz, tuzlu su ile } \\
\text { tuzlanmış veya kuru } \\
\text { tuzlanmış levrek } \\
\text { filetolarının in vitro } \\
\text { sindirim }\end{array}$ & $\begin{array}{c}\text { Sindirim öncesinde yöntemlerin hiçbirinde lipit oksidasyonu } \\
\text { tetiklenmemiştir. Sindirim sonrasında, tuzun yoğunluğuna } \\
\text { bakılmaksızın, tuzlamanın balıkta lipit oksidasyonunun artmasına } \\
\text { neden olabileceği görülmüştür. Bununla birlikte, kuru tuzlama yapılan } \\
\text { balık, diğerlerine göre in vitro sindirim sırasında en yüksek oranda } \\
\text { oksidasyona uğramışı̧ı. }\end{array}$ & $\begin{array}{l}\text { Nieva- } \\
\text { Echevarrí } \\
\text { a ve ark., } \\
2017\end{array}$ \\
\hline Somon fileto & $\begin{array}{l}\text { Tuz ilavesiz ve } \% 1,5 \text { tuz } \\
\text { ilave edilerek pişirme }\end{array}$ & Tuz ilavesinin lipit oksidasyonuna etkisi anlamlı bulunmamıştır. & $\begin{array}{l}\text { Kong ve } \\
\text { ark., } 2008\end{array}$ \\
\hline $\begin{array}{l}\text { Hindi ve } \\
\text { domuz eti }\end{array}$ & $\begin{array}{l}\% 1 \mathrm{NaCl} \text { ilavesi ile kiyma } \\
\text { haline getirme, pişirme, } \\
\text { depolama }\end{array}$ & $\begin{array}{c}\text { Tuzun }(\% 1 \mathrm{NaCl}) \text { kıyma haline getirilmiş, pişirilmiş, depolanmış, } \\
\text { hindi ve domuz etinde lipit oksidasyonu üzerinde önemli bir etkisi } \\
\text { bulunmamıştı. }\end{array}$ & $\begin{array}{l}\text { Vara- } \\
\text { Ubolve } \\
\text { Bowers, } \\
2001\end{array}$ \\
\hline Domuz eti & $\begin{array}{l}\text { Tuz ilavesiz, } \% 1 \text { ve } \% 2 \text { tuz } \\
\text { ilaveli, } 0{ }^{\circ} \mathrm{C} \text { 'de } 3 \text { gün } \\
\text { saklama }\end{array}$ & $\begin{array}{l}\text { Heksanal ve malondialdehit içeriği haşlama ile değişmemiştir. } \\
\text { Depolama sonunda tuz içeren etin heksanal değeri değişmezken tuz } \\
\text { içermeyen etin artmıştır. Çiğ etin aksine haşlanmış ette tuz ilavesi } \\
\text { heksanal oluşumunu önlemiştir. } \\
\text { Depolama süresi boyunca tuz ilave edilen ve edilmeyen et arasında } \\
\text { MDA açısından fark görülmemiştir. Çiğ etin aksine haşlanmış ette tuz } \\
\text { ilavesi pro-oksidan görevi görmemiştir. }\end{array}$ & $\begin{array}{l}\text { Sakai ve } \\
\text { ark., } 2006\end{array}$ \\
\hline
\end{tabular}




\begin{tabular}{|c|c|c|c|}
\hline \multicolumn{2}{|c|}{ Hazırlama ve pişirme } & & \\
\hline Sığır eti & $\begin{array}{l}\text { Haşlama, mikrodalga, } \\
\text { 1zgara pişirme }\end{array}$ & $\begin{array}{c}\text { Sığır etindeki TBARS artışı, diğer pişirme yöntemleri ve çiğ et ile } \\
\text { karşılaştırıldığında sadece haşlama yönteminde artmıştır. }\end{array}$ & $\begin{array}{l}\text { Alfaia ve } \\
\text { ark., } 2010\end{array}$ \\
\hline Domuz eti & $\begin{array}{l}\text { Izgara, mikrodalga, } \\
\text { kızartma, firında pişirme } \\
\text { yöntemleri }\end{array}$ & $\begin{array}{l}\text { En yüksek oksidasyon seviyesi kavrulmuş ve kızartılmış ette } \\
\text { bulunmuş, bunları mikrodalga ve 1zgara takip etmiştir. Izgara yöntemi } \\
\text { diğerlerine göre lipid oksidasyonundan en az etkilenen yöntem } \\
\text { olmuştur. }\end{array}$ & $\begin{array}{l}\text { Broncano } \\
\text { ve ark., } \\
2009\end{array}$ \\
\hline Kuzu eti & $\begin{array}{l}\text { Izgara }\left(150{ }^{\circ} \mathrm{C}\right) \text { ve sous- } \\
\text { vide }\left(75^{\circ} \mathrm{C}\right)\end{array}$ & $\begin{array}{l}\text { Sous-vide pişirme yönteminde izgara yöntemine göre daha düşük } \\
\text { MDA oluşmuştur. }\end{array}$ & $\begin{array}{l}\text { Ortuño ve } \\
\text { ark., } 2020\end{array}$ \\
\hline Tavşan eti & $\begin{array}{l}\text { Fırında pişirme }\left(180^{\circ} \mathrm{C}, 1\right. \\
\text { sa), sous-vide }\left(72,5^{\circ} \mathrm{C}, 2,5\right. \\
\text { sa) ve haşlama }\left(100^{\circ} \mathrm{C}, 20\right. \\
\text { dk) }\end{array}$ & $\begin{array}{l}\text { Çiğ ete göre firınlanmış, sous-vide ve haşlanmış ette sırasıyla yaklaşık } \\
13,7,5 \text { ve } 6 \text { kat daha yüksek peroksit değeri bulunmuştur. }\end{array}$ & $\begin{array}{l}\text { Rasinska } \\
\text { ve ark., } \\
2019\end{array}$ \\
\hline Balık fileto & $\begin{array}{l}\text { Haşlama }\left(98^{\circ} \mathrm{C}, 12 \mathrm{dk}\right) \text {, } \\
\text { firında }\left(250^{\circ} \mathrm{C}, 20 \mathrm{dk}\right), \\
\text { mikrodalga (güç } 10,2 \mathrm{dk}), \\
\text { 1zgara }\left(350^{\circ} \mathrm{C}, 10 \mathrm{dk}\right), \\
\text { soya yağ } 1, \text { kanola yağ } 1 \text { ve } \\
\text { hidrojene bitkisel yağda } \\
\text { kızartma }\left(215-220^{\circ} \mathrm{C}\right)\end{array}$ & $\begin{array}{l}\text { En yüksek MDA artışı mikrodalga ve firın olmak üzere, haşlama, } \\
\text { mikrodalga ve firında pişirme yöntemlerinde artış görülmüştür. Izgara } \\
\text { ve kızartma yöntemlerinde artış anlamlı bulunmamıştır. }\end{array}$ & $\begin{array}{l}\text { Weber ve } \\
\text { ark., } 2008\end{array}$ \\
\hline
\end{tabular}

\section{Kaynakça}

Aday, M. S. Meyve ve Sebzelerde Aktif Ambalajlama Teknolojisinin Kullanımı. (2021). Avrupa Bilim ve Teknoloji Dergisi, (21), 122-130.

Alfaia, C. M., Alves, S. P., Lopes, A. F., Fernandes, M. J., Costa, A. S., Fontes, C. M., ... \& Prates, J. A. (2010). Effect of cooking methods on fatty acids, conjugated isomers of linoleic acid and nutritional quality of beef intramuscular fat. Meat Science, 84(4), 769-777.

Amaral, A. B., Silva, M. V. D., \& Lannes, S. C. D. S. (2018). Lipid oxidation in meat: mechanisms and protective factors-a review. Food Science and Technology, 38, 1-15.

Angeli, J.P.F.; Garcia, C.C.M.; Sena, F.; Freitas, F.P.; Miyamoto, S.; Medeiros, M.H.G.; Di Mascio, P. Lipid hydroperoxideinduced and hemoglobin-enhanced oxidative damage to colon cancer cells. Free Radic. Biol. Med. 2011, 51, 503-515.

Barden, L., \& Decker, E. A. (2016). Lipid oxidation in lowmoisture food: a review. Critical reviews in food science and nutrition, 56(15), 2467-2482.

Barriuso, B., Astiasarán, I., \& Ansorena, D. (2013). A review of analytical methods measuring lipid oxidation status in foods: a challenging task. European food research and technology, 236(1), 1-15.

Broncano, J. M., Petrón, M. J., Parra, V., \& Timón, M. L. (2009). Effect of different cooking methods on lipid oxidation and formation of free cholesterol oxidation products (COPs) in Latissimus dorsi muscle of Iberian pigs. Meat science, 83(3), 431-437.

Coombs, C. E., Holman, B. W., Ponnampalam, E. N., Morris, S., Friend, M. A., \& Hopkins, D. L. (2018). Effects of chilled and frozen storage conditions on the lamb M. longissimus lumborum fatty acid and lipid oxidation parameters. Meat science, 136, 116-122.

Domínguez, R., Pateiro, M., Gagaoua, M., Barba, F. J., Zhang, W., \& Lorenzo, J. M. (2019). A comprehensive review on lipid oxidation in meat and meat products. Antioxidants, 8(10), 429.
Faustman, C., Sun, Q., Mancini, R., \& Suman, S. P. (2010). Myoglobin and lipid oxidation interactions: Mechanistic bases and control. Meat science, 86(1), 86-94.

Gheisari, H. R., Møller, J. K., Adamsen, C. E., \& Skibsted, L. H. (2010). Sodium chloride or heme protein induced lipid oxidation in raw, minced chicken meat and beef. Czech Journal of Food Sciences, 28(5), 364-375.

Gheisari, H. R., \& Motamedi, H. (2010). Chloride salt type/ionic strength and refrigeration effects on antioxidant enzymes and lipid oxidation in cattle, camel and chicken meat. Meat science, 86(2), 377-383.

Guyon, C., Meynier, A., \& de Lamballerie, M. (2016). Protein and lipid oxidation in meat: A review with emphasis on highpressure treatments. Trends in Food Science \& Technology, 50, 131-143.

Huang, X., \& Ahn, D. U. (2019). Lipid oxidation and its implications to meat quality and human health. Food science and biotechnology, 28(5), 1275-1285.

Jin, G., He, L., Zhang, J., Yu, X., Wang, J., \& Huang, F. (2012). Effects of temperature and $\mathrm{NaCl}$ percentage on lipid oxidation in pork muscle and exploration of the controlling method using response surface methodology (RSM). Food Chemistry, 131(3), 817-825.

Kanner, J. Dietary advanced lipid oxidation endproducts are risk factors to human health. Mol. Nutr. Food Res. 2007, 51, 1094-1101.

Kong, F., Oliveira, A., Tang, J., Rasco, B., \& Crapo, C. (2008). Salt effect on heat-induced physical and chemical changes of salmon fillet (O. gorbuscha). Food Chemistry, 106(3), 957966.

Králová, M. (2015). The effect of lipid oxidation on the quality of meat and meat products. Maso Int. J. Food Sci. Technol, 2, 125-132.

Macho-González, A., Garcimartín, A., López-Oliva, M. E., Bastida, S., Benedí, J., Ros, G., ... \& Sánchez-Muniz, F. J. (2020). Can Meat and Meat-Products Induce Oxidative Stress?. Antioxidants, 9(7), 638.

Mariutti LRB, Bragagnolo N. (2017). Influence of salt on lipid oxidation in meat and seafood products: a review. Food Res. Int. 94: 90-100 
McMillin, K. W. (2017). Advancements in meat packaging. Meat science, 132, 153-162.

Min, B., \& Ahn, D. U. (2005). Mechanism of lipid peroxidation in meat and meat products-A review. Food Science and Biotechnology, 14(1), 152-163.

Min, B., Nam, K. C., Cordray, J., \& Ahn, D. U. (2008). Endogenous factors affecting oxidative stability of beef loin, pork loin, and chicken breast and thigh meats. Journal of Food Science, 73(6), C439-C446.

Min, B., Cordray, J. C., \& Ahn, D. U. (2010). Effect of $\mathrm{NaCl}$, myoglobin, $\mathrm{Fe}$ (II), and $\mathrm{Fe}$ (III) on lipid oxidation of raw and cooked chicken breast and beef loin. Journal of agricultural and food chemistry, 58(1), 600-605.

Muela, E., Monge, P., Sañudo, C., Campo, M. M., \& Beltrán, J. A. (2015). Meat quality of lamb frozen stored up to 21 months: Instrumental analyses on thawed meat during display. Meat science, 102, 35-40.

Nieva-Echevarría, B., Goicoechea, E., Manzanos, M. J., \& Guillén, M. D. (2017). Fish in vitro digestion: influence of fish salting on the extent of lipolysis, oxidation, and other reactions. Journal of agricultural and food chemistry, 65(4), 879-891.

Orkusz, A., Haraf, G., Okruszek, A., \& Wereńska-Sudnik, M. (2017). Lipid oxidation and color changes of goose meat stored under vacuum and modified atmosphere conditions. Poultry science, 96(3), 731-737.

Ortuño, J., Mateo, L., Rodríguez-Estrada, M. T., \& Bañón, S. (2020). Effects of sous vide vs grilling methods on lamb meat colour and lipid stability during cooking and heated display. Meat Science, 171, 108287.

Papuc, C.; Goran, G.V.; Predescu, C.N.; Nicorescu, V. Mechanisms of oxidative processes in meat and toxicity induced by postprandial degradation products: A review. Compr. Rev. Food Sci. Food Saf. 2017, 16, 96-123.

Pereira, P. M. D. C. C., \& Vicente, A. F. D. R. B. (2013). Meat nutritional composition and nutritive role in the human diet. Meat science, 93(3), 586-592.

Purohit, A., Singh, R., Kerr, W., \& Mohan, A. (2015). Effects of heme and nonheme iron on meat quality characteristics during retail display and storage. Journal of Food Measurement and Characterization, 9(2), 175-185.

Rasinska, E., Rutkowska, J., Czarniecka-Skubina, E., \& Tambor, K. (2019). Effects of cooking methods on changes in fatty acids contents, lipid oxidation and volatile compounds of rabbit meat. LWT, 110, 64-70.

Ross, C.F.; Smith, D.M. Use of volatiles as indicators of lipid oxidation in muscle foods. Compr. Rev. Food Sci. Food Saf. 2006, 5, 18-25.

Sakai, T., Shimizu, Y., \& Kawahara, S. (2006). Effect of $\mathrm{NaCl}$ on the lipid peroxidation-derived aldehyde, 4-hydroxy-2nonenal, formation in boiled pork. Bioscience, biotechnology, and biochemistry, 70(4), 815-820.

Scollan, N. D., Price, E. M., Morgan, S. A., Huws, S. A., \& Shingfield, K. J. (2017). Can we improve the nutritional quality of meat?. Proceedings of the Nutrition Society, 76(4), 603-618.

Soyer, A., Özalp, B., Dalmış, Ü., \& Bilgin, V. (2010). Effects of freezing temperature and duration of frozen storage on lipid and protein oxidation in chicken meat. Food chemistry, 120(4), 1025-1030.

Steppeler, C., Haugen, J. E., Rødbotten, R., \& Kirkhus, B. (2016). Formation of malondialdehyde, 4-hydroxynonenal, and 4hydroxyhexenal during in vitro digestion of cooked beef, pork, chicken, and salmon. Journal of agricultural and food chemistry, 64(2), 487-496.

Suman, S. P., Mancini, R. A., Joseph, P., Ramanathan, R., Konda, M. K. R., Dady, G., \& Yin, S. (2010). Packaging-specific influence of chitosan on color stability and lipid oxidation in refrigerated ground beef. Meat Science, 86(4), 994-998.

Van Hecke, T., Vossen, E., Bussche, J. V., Raes, K., Vanhaecke, L., \& De Smet, S. (2014). Fat content and nitrite-curing influence the formation of oxidation products and NOCspecific DNA adducts during in vitro digestion of meat. PLoS One, 9(6), e101122.

Van Hecke, T., Wouters, A., Rombouts, C., Izzati, T., Berardo, A., Vossen, E., ... \& De Smet, S. (2016b). Reducing compounds equivocally influence oxidation during digestion of a high-fat beef product, which promotes cytotoxicity in colorectal carcinoma cell lines. Journal of agricultural and food chemistry, 64(7), 1600-1609.

Van Hecke, T.; Jakobsen, L.M.; Vossen, E.; Guéraud, F.; De Vos, F.; Pierre, F.; Bertram, H.C.; De Smet, S. Short-term beef consumption promotes systemic oxidative stress, TMAO formation and inflammation in rats, and dietary fat content modulates these effects. Food Funct. 2016, 7, 3760-3771.

Vara-Ubol, S., \& Bowers, J. A. (2001). Effect of $\alpha$-tocopherol, $\beta$ carotene, and sodium tripolyphosphate on lipid oxidation of refrigerated, cooked ground turkey and ground pork. Journal of food science, 66(5), 662-667.

Wang, Z., He, Z., Zhang, D., Li, H., \& Wang, Z. (2020). Using oxidation kinetic models to predict the quality indices of rabbit meat under different storage temperatures. Meat science, 162, 108042.

Weber, J., Bochi, V. C., Ribeiro, C. P., Victório, A. D. M., \& Emanuelli, T. (2008). Effect of different cooking methods on the oxidation, proximate and fatty acid composition of silver catfish (Rhamdia quelen) fillets. Food Chemistry, 106(1), 140-146. 